\title{
Usage of Natural Colour Indicators in Packaging Materials for Monitorization of Meat Freshness
}

\author{
Pelin Özkaya ${ }^{1, a, *}$, Seval Dağbağ $I_{1}^{2, b}$ \\ ${ }^{1}$ Department of Food Engineering, Faculty of Engineering, Manisa Celal Bayar University, 45030 Manisa, Turkey
} *Corresponding author

\begin{tabular}{l|l}
\hline A R T I C L E I N F O & A B S T R A C T \\
\hline & Food packaging has an important role in protecting food against physical, chemical, and biological
\end{tabular}

Review Article hazards during storage and distribution and in informing the consumer about the product. The packaging of foods that susceptible to chemical / microbiological spoilage especially such as meat, hence limited storage time, is even more important than other foods. In addition, the tendency of

Received : 10/05/2021

Accepted : 06/07/2021 health-conscious consumers to be a part of real-time controls and monitoring food safety has led to the widening of this packaging perception. Hence, there have been innovative studies in recent years, especially aiming real time monitorization of freshness indicators. The focus of these studies is "colour indicators" used in the production of intelligent indicator films and colorimetric sensors within specific matrices to be integrated into packaging materials. The colour indicators change

Keywords: Colour indicators Intelligent packaging Meat freshness Natural pigments Visual monitorization colour in the presence of certain metabolites released in food spoilage, which allows freshness to be determined. Colour substances used for this purpose can be natural or synthetic. Hence, natural pigments such as anthocyanin, curcumin, etc. have been more preferrable since being harmless to the health as well as increasing tendency of consumers to utilization from natural resources. In this review, information about natural colour indicators and studies in which these indicators are used to determine the freshness of meat in real time and visually are given.

Türk Tarım - Gıda Bilim ve Teknoloji Dergisi, 9(10): 1869-1875, 2021

\section{Ette Tazeliğin İzlenmesine Yönelik Olarak Ambalaj Materyallerinde Doğal Renk İndikatörlerinin Kullanımı}

\begin{tabular}{|c|c|}
\hline M A K A LE B İ L G İ I İ & Ö Z \\
\hline $\begin{array}{l}\text { Anahtar Kelimeler: } \\
\text { Renk indikatörleri } \\
\text { Akı1lı ambalajlama } \\
\text { Ette tazelik } \\
\text { Doğal pigmentler } \\
\text { Görsel izleme }\end{array}$ & $\begin{array}{l}\text { Gıda ambalajları, gidanın depolama ve dağıtımı sırasında fiziksel, kimyasal ve biyolojik tehlikelere } \\
\text { karşı korunmasında ve tüketicinin ürün hakkında bilgilendirilmesinde önemli bir role sahiptir. } \\
\text { Özellikle et gibi kimyasal / mikrobiyolojik bozulmaya duyarlı, dolayısıla saklama süresi sınırlı olan } \\
\text { gıdaların ambalajlanması diğer gıdalara göre daha önemlidir. Bir de sağlık bilincine sahip tüketicilerin } \\
\text { gıda güvenliğini izlemek ve gerçek zamanlı kontrollerin bir parçası olmak istemesi bu ambalaj } \\
\text { algısının kapsamının genişlemesine yol açmıştır. Bu nedenle, son yıllarda özellikle tazelik } \\
\text { indikatörlerinin gerçek zamanlı izlenmesini amaçlayan yenilikçi çalışmalar yapılmıştır. Bu } \\
\text { çalışmaların odak noktası, ambalaj malzemelerine entegre edilecek belirli matriksler içerisinde, akıllı } \\
\text { indikatör filmlerin ve kolorimetrik sensörlerin üretiminde kullanılan "renk indikatörleri" dir. Renk } \\
\text { indikatörleri, gıdanın bozulmasında açığa çıan belirli metabolitlerin varlığında renk değiştirmekte ve } \\
\text { bu da tazeliğin belirlenebilmesine olanak vermektedir. Bu amaçla kullanılan renk maddeleri doğal } \\
\text { veya sentetik olabilir. Antosiyanin, kurkumin gibi doğal renk maddeleri, sağlik açısından zararsı } \\
\text { olmaları ve tüketicilerin doğal kaynaklardan yararlanma eğilimi nedeniyle öne çıkmaktadır. Bu } \\
\text { derlemede doğal renk indikatörleri ve bu indikatörlerin etin tazeliğinin gerçek zamanlı ve görsel } \\
\text { olarak belirlenmesi amacıyla kullanıldığ çalışmalar ile ilgili bilgiler verilmiştir. }\end{array}$ \\
\hline
\end{tabular}




\section{Introduction}

Meat is known to be a vulnerable food material against to microbiological spoilage which may cause poisonings and economical losses. There is an increasing demand for a nutritious and high-quality food which has a parallel tendency with increasing diet and health awareness and income of individuals especially in developed countries (Özkaya and Kayaard1, 2018). Recently, further satisfaction of consumer expectations is also considered and new technologies are emerging in order to enable real time visual monitorization of meat freshness. Major starting point of related researches is chemical, microbiological and $\mathrm{pH}$ changes in meat which tends to lose freshness as the time passes. Hence, freshness criteria come into view by evaluation of these changes.

Major freshness criteria of meat can be aligned as total volatile basic nitrogen (TVB-N), hypoxhantine/xhantine, hydrogen sulphure $\left(\mathrm{H}_{2} \mathrm{~S}\right)$, ammonia $\left(\mathrm{NH}_{3}\right)$ level, $\mathrm{pH}$ and microbiological parameters (total mesophilic aerobic, coliform and yeast and mould counts) (Fu et al., 2019). Due to release of these substances or concentration increase and even $\mathrm{pH}$ change, there occurs a colour change within susceptive packaging material which can be recognized by naked eye. Therefore, consumer-based freshness detection becomes possible. In this frame, intelligent packaging system and its basic ingredient within special films, indicators- (Dudnyk et al., 2018; Zhai et al., 2019; Mohammadalinejhad et al., 2020), have been used in many researches. Especially, there are successful indicator films which are integrated into fresh meat packages that make possible real time freshness control of the product. This review aims to evaluate natural colour indicators which are being used for packaging many kinds of meat.

\section{Natural Colour Indicators and Their Usage for Intelligent Packaging}

Colour indicators are defined as qualitative and semiquantitative detection tools that reflects the present status of the product via colour changes (Zhai et al., 2019). They are integrated into packaging materials and hence, meat freshness can be detected.

Natural or synthetic substances can be obtained from several kinds of sources and fixed into suitable materials to be used within packages for expected functions. Due to formation of several metabolites such as $\mathrm{CO}_{2}, \mathrm{SO}_{2}, \mathrm{NH}_{3}$, colour of the synthetic indicators, including xylene blue, bromcresole blue, cresole, phenol phytalein, etc. may change (Çelik and Tümer, 2016). However, possible toxic and carcinogenic features of those synthetic colour indicators have resulted in a considerable interest towards natural sources (Roy and Rhim, 2020). For instance, natural colour substances such as curcumin, betalain, anthocyanins, carotenoids and chlorophyll which are derived from plants and root vegetables have been considered as ideal $\mathrm{pH}$-sensitive indicators for this purpose. Moreover, these natural colour indicators are used within biodegradable films containing chitosan, starch, polylactide, polyhydroxybutyrate, etc. (Latos-Brozio and Masek, 2020). On the other hand, methods of film production also have several alternatives that integration of indicator substances into the packaging materials can be performed by solution casting method (Roy and Rhim, 2020), lamination technique (Lee et al., 2020), extrusion method (Zhai et al., 2020) or electrospinning (Aghaei et al., 2020). Therefore, usage of natural colorants in intelligent packaging concept is evaluated for several kinds of meat and meat products including seafood for easy and real time visual detection of freshness.

\section{Anthocyanins}

Anthocyanins are defined as one category of phenolic compounds that can be derived from several sources such as purple sweet potato (Jiang et al., 2020; Li et al., 2021), red cabbage, (Dudnyk et al., 2018), mulberry (Zeng et al., 2019), etc. and mentioned as excellent antioxidant, antimicrobial and $\mathrm{pH}$-sensitive water-soluble natural colorants. Anthocyanins contain a huge group of molecules with a plenty of biological functions including antiinflammatory, anti-proliferative and anti-carcinogenic activities and take an important place in the group of bioactive compounds because of these functional properties. Anthocyanins exist within the group of polyphenols which has also been the most abundant group in nature together with flavonoids, flavones, flavanones, isoflavones, catechins, phenolic acids, and tannins phytoestrogens, stilbenes, and curcuminoids (Filho et al., 2021). Since the name, -anthocyanins-, refers to a chemical group, there has not been a single substance with a unique colour, there have been hundreds of identified anthocyanin molecules up to now and they are separated into six groups (pelargonidin, cyanidin, delphinidin, peonidin, petunidin and malvidin) according to their basic structures. There exist some colour variations depending on the source of anthocyanin molecule and $\mathrm{pH}$ which include a wide colour spectrum from light pink to dark purple/blue and brownish tones (Yong and Liu, 2020). This colour changing character of anthocyanins is attributed to different groups attached at each position of the molecule and the acids attached to them, resulting in the formation of a $\mathrm{pH}$ dependent visible colour (Filho et al., 2021). Thus, an aqueous solution of an anthocyanin extract can demonstrate a colorimetric change from red or pink at $\mathrm{pH}$ $<7$, purple at $\mathrm{pH} \approx 7$, green-yellow at $\mathrm{pH}>7$, and colorless in a highly alkaline medium. They are also nontoxic as they are a constituent in a variety of plants and have been used as a coloring additive in foodstuffs. Moreover, they demonstrated biological activities, such as anticancer, as well as antioxidant due to their ability to quench active oxygen species (Yong and Liu, 2020).

As it is mentioned that anthocyanins have a good potential to utilize in intelligent packaging applications, which are considered as safe to be used and abundant in the nature as well as their good colorimetric indicator properties. So, anthocyanins are considered as effective molecules for detection of meat freshness via intelligent packaging because of their sensitive nature to the substances which are released from meat during spoilage since the research of Huang et al. (2014) showed it with a comparative study. In the present study, reddish (Raphanus sativus L.) and black rice (Oryza sativa L. indica) extract anthocyanins were used in addition to carotene and chlorophyll natural pigments of spinach (Spinacia 
oleracea) and winter jasmine (Jasminum nudiflorum) to detect the presence of biogenic amines in pork meat. The most sensitive pigment to biogenic amines was found to be black rice anthocyanins. This performance was attributed to the interaction between hydroxyl and carbonyl groups of anthocyanin molecule and the analytes. It can also be seen that, there have been many different anthocyanin molecules resulting in variations in performance between each other within this chemical group. Thus, anthocyanin molecules of reddish and black rice anthocyanins acted differently that the latter's performance was superior. Actually, there have been a wide variety of examples related to anthocyanin-based intelligent packages. Dudnyk et al. (2018) succeeded to manufacture an edible sensor film which was containing red cabbage anthocyanins. The film was also advantageous to be appropriate for several product groups such as beef, chicken, fish, shrimp. Colour of the film was turning from purple to yellow due to formation of amines as a result of spoilage, which was possible to recognize easily. As another example, Kürek et al. (2019) produced an intelligent packaging film from blueberry and red grape skin pomace extracts that were immobilized on chitosan and carboxymethyl cellulose polymer matrices to determine chicken meat freshness. When $\mathrm{pH}$ changes due to spoilage, colour of the films turned to green and orange according to containing blueberry and red grape skin pomace extract anthocyanins, respectively. Jiang et al. (2020) also used a similar polymer matrix but another source of anthocyanin to manufacture an intelligent package. It was including carboxy methyl cellulose/starch and sweet purple potato anthocyanins to determine fish freshness. The film was especially sensible to ammonia and colour of the film (initially red) turned to blue-green as its concentration increased within the pack. On the other hand, flowers are also considered as a good source for natural pigments that, Zhang et al. (2021) produced a multi-layered packaging film, in which hydrophobic polyvinylidene fluoride film was a moisture prevent-layer and the sensor layer was provided based on polyvinyl alcohol/sodium alginate and roselle anthocyanins. Freshness change of griskin, a kind of meat product manufactured from pork, was determined with colour change from pinky tones to yellow/brownish colours $\mathrm{pH}$ change caused by TVB-N formation.

Sources of anthocyanins and appropriate matrices to be integrated have a wide variety of alternatives in addition to being abundant in the nature that, indicated properties of anthocyanins have encouraged many researchers to manufacture new natural-based colorimetric films for meat packaging and also consumer-based freshness monitoring. These researches are shown on Table 1 for meat and poultry and seafood.

Table 1. Anthocyanin-based packaging films according to different types of meat and seafood.

\begin{tabular}{|c|c|c|c|c|}
\hline Package film content & Product & Function mechanism & Colour & Reference \\
\hline $\begin{array}{l}\text { Edible sensor from red cabbage } \\
\text { anthocyanins with pectin }\end{array}$ & $\begin{array}{l}\text { Beef, chicken, } \\
\text { fish, shrimp }\end{array}$ & Amines & From purple to yellow & Dudnyk et al., 2018 \\
\hline $\begin{array}{l}\text { Chitosan/Starch/ PVA and Roselle } \\
\text { calyx anthocyanins }\end{array}$ & Pork & pH (TVB-N) & Red- Green- Yellow & Zhang et al., 2019 \\
\hline $\begin{array}{l}\text { Gelatine/poly viny alcohol and } \\
\text { black berry extract anthocyanins }\end{array}$ & Fish & TVB-N & $\begin{array}{l}\text { From bright red to } \\
\text { dark green }\end{array}$ & Zeng et al., 2019 \\
\hline $\begin{array}{l}\text { Bacterial cellulose nanofibers and } \\
\text { black carrot anthocyanins }\end{array}$ & Fish & pH (TVB-N) & $\begin{array}{l}\text { From charm pink color } \\
\text { to jellybean blue and } \\
\text { khaki colors }\end{array}$ & Moradi et al., 2019 \\
\hline $\begin{array}{l}\text { Blueberry and red grape skin } \\
\text { pomace extracts immobilized on } \\
\text { chitosan and carboxymethyl } \\
\text { cellulose polymer matrices }\end{array}$ & Chicken meat & $\mathrm{pH}$ & $\begin{array}{c}\text { Towards green in } \\
\text { blueberry-based film } \\
\text { and towards orange in } \\
\text { grape seed extract- } \\
\text { based film }\end{array}$ & Kürek et al., 2019 \\
\hline $\begin{array}{l}\text { Polyvinyl alcohol/okra mucilage } \\
\text { polysaccharide incorporated with } \\
\text { rose anthocyanins }\end{array}$ & Shrimp & $\begin{array}{l}\mathrm{pH} \text { (Volatile } \\
\text { ammonia) }\end{array}$ & $\begin{array}{l}\text { Towards dark green } \\
\text { (purple } \rightarrow \text { blue } \rightarrow \text { dark- } \\
\text { green } \rightarrow \text { yellow) }\end{array}$ & Kang et al., 2019 \\
\hline $\begin{array}{l}\text { Starch/PVA and sweet purple } \\
\text { potato and red cabbage } \\
\text { anthocyanins }\end{array}$ & Shrimp & pH (TVB-N) & $\begin{array}{l}\text { Light Purple-Bright } \\
\text { Red- Blue- Green }\end{array}$ & Zhang et al., 2020 \\
\hline $\begin{array}{l}\text { Jambolan fruit anthocyanins and } \\
\text { agarose Solution }\end{array}$ & Chicken & pH (TVB-N) & Pink to yellow & Talukder et al., 2020 \\
\hline $\begin{array}{l}\text { Bacterial cellulose and Echium } \\
\text { amoenum anthocyanins }\end{array}$ & Shrimp & $\mathrm{pH}$ & From violet to yellow & $\begin{array}{l}\text { Mohammadalinejhad } \\
\text { et al., } 2020\end{array}$ \\
\hline $\begin{array}{l}\text { Methylcellulose/chitosan nanofiber } \\
\text { and barberry anthocyanins }\end{array}$ & $\begin{array}{l}\text { Meat and } \\
\text { seafood }\end{array}$ & $\begin{array}{l}\mathrm{NH}_{3} / \mathrm{VBN} \\
\text { formation-pH }\end{array}$ & $\begin{array}{l}\text { From pink to green } \\
\text { and finally yellow }\end{array}$ & $\begin{array}{l}\text { Alizadeh-Sani et al., } \\
2020\end{array}$ \\
\hline $\begin{array}{l}\text { Halochromic nanocellulose label } \\
\text { (containing grape anthocyanins) }\end{array}$ & Meat & pH (TVB-N) & $\begin{array}{l}\text { From bright red to } \\
\text { purplish red }\end{array}$ & $\begin{array}{l}\text { Taherkhani et al., } \\
2020 .\end{array}$ \\
\hline $\begin{array}{l}\text { Hydrophobic Polyvinylidene } \\
\text { Fluoride film as a moisture } \\
\text { prevent-layer and the sensor layer } \\
\text { was provided based on polyvinyl } \\
\text { alcohol/sodium alginate and } \\
\text { roselle anthocyanins }\end{array}$ & Griskin & pH (TVB-N) & $\begin{array}{l}\text { From pinky tones to } \\
\text { yellow/brownish } \\
\text { colors }\end{array}$ & Zhang et al., 2021 \\
\hline
\end{tabular}




\section{Curcumin}

Curcumin is obtained from turmeric and it is used as a kind of spice and a natural colour pigment. It is produced from Curcuma longa (Zingiberaceae) tropical plant which is cultivated in several Asian countries such as India, China, Indonesia and has a bitterish taste similar to ginger. Curcumin is defined as a low-molecular weight polyphenolic compound. But demethoxycurcumin and bisdemethoxycurcumin also exist other than curcumin (diferulylmethane) that, these three are called as curcuminoids together (Er, 2016). Curcuminoids are commonly used which also considered as a kind of alternative treatment for several health problems including asthma, sinusitis, hepatic disorders, rheumatism, diabetic wounds, etc. Moreover, curcumin has been considered as a cure for poisoning, snakebites or a treatment of some parasites. It is also listed in the international numbering system for food additives. Because, curcumin is accepted as a safe coloring agent which gives a sharp yellow colour after addition to the food (Katmer, 2015). In addition, antiinflammation, anticancer and antiviral characteristics of curcumin are also mentioned in literature. But similar to the anthocyanins, curcumin is also a $\mathrm{pH}$-sensitive pigment and its colour changes from yellow to orange/reddish tones because of phenoxide anion formation (Y1ldiz et al., 2021). This property has recently drawn more attention for colorimetric indicator studies and intelligent packaging of foodstuff. So, there has been another area of utilization, in addition to present functions of curcumin. Therefore, it has become much more popular compared to the past (Chen et al., 2020). For instance, Liu et al. (2018) produced a packaging film with curcumin and $\kappa$-carrageenan for packaging shrimp and pork and successfully monitored freshness change due to TVB-N formation resulting in $\mathrm{pH}$ change of the packaging environment. For fish and beef, Zhai et al. (2020) manufactured a hydrophobic ammonia sensor (extruded low-density polyethylene-curcumin film) which was sensitive to $\mathrm{NH}_{3}$ and other volatile amines. In this research, integration technique of the pigment was based on extrusion which also shows that there might be different methods in production of pigment containing packaging films. Hence, electrospinning is another alternative that, Y1ld1z et al. (2021) obtained electrospin nanofibers from curcumin loaded chitosan and polyethylene oxide nanofibers. Sensitivity of the nanofibers to TVB-N enabled visual determination of chicken meat freshness.
Natural pigments can also be used together. There has been recent research in which starch, polyvinyl alcohol (SPVA) and glycerol-based film was used with anthocyanin and curcumin. Three different colour formations could be achieved, representing freshness, medium freshness and spoilage of fish in SPVA/Glycerol film (curcumin and anthocyanin ratio was 2:8 (v/v)) (Chen et al., 2020). In another research, konjac glucomannan/ camellia oil and carrageenan/anthocyanin/curcumin-based $\mathrm{pH}$-responsive double-layer indicator films had been manufactured and successfully enabled visual detection of meat freshness. It was shown that combined usage of curcumin and anthocyanin gave more obvious colour change and provided sensitivity increase (Zhou et al., 2021). Nevertheless, curcumin has been going on to be used alone in this field and some researches based on producing curcumin containing indicator or sensor films for meat packaging and visualizing change in freshness are shown on Table 2.

\section{Other Natural Colour Indicators}

Researchers have also benefited from several other natural pigments and reproduced alternatives to manufacture intelligent packages. Alizarin is one of them as a multifunctional natural pigment which is mainly used in pharmaceutical and food industries. Plant roots are its natural sources that, it is also called as Turkey Red. Production of indicators from alizarin is performed by ionisation and deprotonation of hydroxyl groups within phenolic compounds of that pigment (Ezati et al., 2020). Cellulose/chitosan-based film of alizarin was used for intelligent packaging of minced beef which had reversible colour changes from yellow to purple between $\mathrm{pH} 2-12$ (Ezati et al., 2019). Aghaei et al. (2018) also manufactured a real time fish spoilage indicator to be used as onpackaging sensor whose colour changes because of TVB$\mathrm{N}$ formation and $\mathrm{pH}$ increment caused by alizarin containing cellulose acetate nanofibers of the halochromic sensor. Aghaei et al. (2020) manufactured another sensor that was designed by electrospin zein nanofibers with alizarin content as indicator dye for detection of rainbow trout fillets. The fillets were preserved at $4^{\circ} \mathrm{C}$ for 12 days that, the sensor was colorless for 4 days while it turned to light purple later and finally it got magenta by the 10.-12. days of cold storage due to TVB-N and TVC formation.

Table 2. Curcumin-based packaging films according to different types of meat and seafood.

\begin{tabular}{|c|c|c|c|}
\hline Package content & Product & Function mechanism & Reference \\
\hline Curcumin from turmeric and $\kappa$-carragenan & Shrimp and pork & $\mathrm{pH}(\mathrm{TVB}-\mathrm{N})$ & Liu et al., 2018 \\
\hline Curcumin + chitosan/ chitosan oxide film & Fish and seafood & $\mathrm{pH}$ & Wu et al., 2019 \\
\hline $\begin{array}{l}\text { Irradiated sodium alginat }(\mathrm{NaAlg}) / \text { acrylamide } \\
\text { (AAm) mix }\end{array}$ & Chicken meat & $\mathrm{pH}$ & Demirel, 2019 \\
\hline $\begin{array}{l}\text { Electrospun nanofibers from Curcumin + poly } \\
\text { vinyl prolydon and ethyl cellulose/polyethylen } \\
\text { oxide }\end{array}$ & Fish and seafood & Volatile amines & Luo et al., 2020 \\
\hline $\begin{array}{l}\text { Hydrofhobic ammonnia sensor (Extruded low- } \\
\text { density polyethylene-curcumin film) }\end{array}$ & Silver carp (fish) and beef & $\begin{array}{l}\mathrm{NH}_{3} \text { and other volatile } \\
\text { amines }\end{array}$ & Zhai et al., 2020 \\
\hline $\begin{array}{l}\text { Curcumin + sulphure nanoparticles with } \\
\text { pectin-based film }\end{array}$ & Shrimp & $\mathrm{pH}$ & $\begin{array}{l}\text { Ezati and Rhim, } \\
2020\end{array}$ \\
\hline Curcumin + agar and polyvinyl alcohol & $\begin{array}{l}\text { Freshwater shrimp } \\
\text { (Macrobrachium } \\
\text { rosenbergii) }\end{array}$ & $\mathrm{NH}_{3}$ & $\begin{array}{l}\text { Zhang et al., } \\
\quad 2021\end{array}$ \\
\hline $\begin{array}{l}\text { Electrospun nanofibers from curcumin loaded } \\
\text { chitosan and polyethylene oxide nanofibers }\end{array}$ & Chicken meat & TVB-N & $\begin{array}{l}\text { Y1ldiz et al., } \\
2021\end{array}$ \\
\hline
\end{tabular}


It was concluded that the alizarin containing sensor was a good alternative for indication of fish spoilage

Shikonin is another alternative which is derived from the root of gromwell (Lithospermum erythrorhizon). It is exactly defined as a red naphthoquinone which is used for a cure for burns and inflammations, other than its colorant character. Recently, it has been used for an intelligent packaging system as a $\mathrm{pH}$-sensitive colour indicator for monitoring the freshness of fish and pork. Colour of the film turned to blue while it was initially red, due to $\mathrm{pH}$ change. It was also reported that the packaging material had gained some other advantageous properties; water resistance and heat stability of the packaging material increased, and antioxidant activity improved. Therefore, shikonin reported to be a good alternative in this field (Ezati et al., 2021). Dong et al. (2020) also studied on colorimetric sensing film for real time monitoring the freshness of shrimp and pork. They used biodegradable cellulose and naphtoquinone dyes extracted from Arnebia euchroma (AENDs) which have alkannin and shikonin as the main pigments to be used as biogenic amines indicator. It was claimed that, use of this material within the packaging film provided a better mechanical strength, colorimeter properties, thermal stability and some other advantages.

On the other hand, betalains are another group of bioactive compounds, which contains water soluble pigments that replace anthocyanins in Caryophyllales plant family that, Kanatt (2020) benefited from the advantages of Amaranthus leaf extract (ALE) which is rich in phenolic compounds and betalain for packaging of fish and chicken. Shelf-life extension during chilled storage could also be succeeded due to antioxidant, antibacterial activity of the package content. It is reported that ALE changed colour from red to yellow under basic conditions due to betalain presence and increase in TVBN concentration had caused it. Finally, it was concluded that incorporation of ALE into PVA-gelatin films have provided an active/intelligent packaging film.

Natural sources can further be varied. In the research of Ian et al. (2020), a colorimetric sensor was designed with genipin which naturally exists in fruit extracts. Genipin was immobilized to edible Ca-alginate and used for chicken packaging, since it is known to interact with biogenic amines (cadaverine, putrescine, tyramine, hystamine). The colour of the sensor had turned to dark blue due to spoilage.

Other natural pigments such as caroten, chlorophyll and lutein have also been in the scope of innovative packaging systems especially together with environmentally friendly biodegradable polymers for food industry, not only for meat packaging (Latos-Brozio and Masek, 2020). Moreover, sources and kind of natural pigments have been extending in time. For instance, a new natural source, Spirulina is defined as a microalgae with its characteristic blue-green colour and rich in $\mathrm{pH}$-sensitive natural pigments such as B-carotene, tocopherols, phycocyanin, phycoerytrin and chlorophylls while it has also legally been on the market as a food supplement due to its composition (rich in high quality proteins and lipids), bioactives (bioactive peptides, PUFAs, vitamins, carotenoids) and functional (anti-hypertensive, anti-obesity, anti-diabetes, anti-oxidant) properties (Lafarga et al., 2020).

Moreira et al. (2018), could successfully use the intense blue coloured pigment phycocyanin from Spirulina within poly lactic acid (PLA) / poly ethylene oxide (PEO) ultrafine nanofibers by electrospinning, while encapsulation of its biomass in polymer nanofibers is also considered as a promising application for developing a colorimetric $\mathrm{pH}$ indicator as also performed by Kuntzler et al. (2020). Usage of Spirulina within intelligent packaging has been going on that, recent research by Terra et al. (2021) was performed for visual estimation of $\mathrm{pH}$ changes depending on quality loss. Time-pH indicator nanofibers were manufactured to monitor the quality of foods by using curcumin and quercetin obtained from vegetable plants and phycocyanin from Spirulina. They concluded that polycaprolactone (PCL)/ (PEO) nanofibers containing 2\% $(\mathrm{w} \mathrm{v}-1)$ of phycocyanin can be a good alternative to detect quality loss of perishable foods such as meat.

These researches obviously show that there exist a wide variety of natural pigments and sources to be utilized within the scope of intelligent and active packaging concept.

\section{Common Challenges and Obstacles}

Stability of these substances are quite important for their expected functions. However, each material is affected by extrinsic factors differently. For instance, curcumin is sensible to light, while betanin and anthocyanins are heat sensitive (Etxabide et al., 2021). Significant information about chemical nature and behaviour and general properties of them is also needed, since they ought to be integrated into appropriate matrices and to be well attached where the main purpose is getting the best performance. In details, anthocyanins are negatively affected by heat, light, metal ions and $\mathrm{pH}$, while it is claimed that stability is mostly affected by its molecular structure. For example, stability decreases as the count of hydroxyl groups existing in the B-ring of the anthocyanidin increases; however, stability increases as the level of methylation increases. There has been another claim that acylation can promote stability increase which had been found with research on blueberry anthocyanins that was treated with maleic acid. It was concluded that, anthocyanins which had been processed with acid treatment can be a good colour indicator for packaging materials (Fei et al., 2021).

It is concluded that production of natural colorimetric packaging materials is a promising field of intelligent packaging applications especially for vulnerable foods such as meat (Takma and Nadeem, 2019). Although they have not been widely used or commercialized, it seems to be succeeded in the future with progressive studies.

\section{Conclusion}

Meat has been an important food material and also an economic value since the ancient times but open to intrinsic and extrinsic threats, especially chemical and microbiological factors. So, detection of its freshness is required to be as possible as easy, accurate and fast. It is 
quite important for prediction/prevention of possible economical loss and/or foodborne diseases as well as meeting health-conscious consumers' expectations for fresh and nutritious food. In this context, freshness criteria of meat should be known first of all. So, formation of biogenic amines, TVBN, hypoxhantine and xhantine, sulphur compounds and $\mathrm{pH}$ changes are determinant other than microbiological parameters. At this point, principle of intelligent packaging to check product freshness is based on selection of a particular substance which is called as "freshness indicator" due to being sensible to the changes caused by spoilage and integration of that indicator into packaging film within a compatible matrix. On the other hand, selected indicator substance can be obtained from natural sources or it can be synthetic. Natural indicator substances are originated from several kinds of plants and fruits and vegetables and regarded as safe to be used in that field. Moreover, they have extra advantages for product protection and health due to their bioactive nature (antioxidant, antimicrobial, anticarcinogenic, antiinflammatory, etc.) while synthetic ones are claimed to be opposite, unhealthy, and have not recently been recommended to use. That's why, main focus of this review was on natural indicators such as anthocyanins, curcumin, alizarin, etc. pigments and related intelligent or active packaging researches instead of the ones with synthetic indicators such as methyl red, bromocresol green, etc. However, the main purpose of those researches is independent from the origin of indicator, since the aim is enabling real time visual monitorization of spoilage via colour changes of special packaging films. Hence, meat freshness can be checked at any time with naked eyes, even by the consumers at the time of purchasing the product or consumption step. Nevertheless, it should be mentioned that, application of this type of packaging have not gained a commercial dimension worldwide. Promising results are taken by academic studies while practical applications sometimes fail due to some obstacles, especially stability problems of natural pigments, but researchers focus on progressive studies and trying to enhance the present status. Moreover, biodegradable polymers and manufacturing eco-friendly packaging materials can be considered as future trends in addition to the usage of natural indicator pigments. Therefore, we conclude that intelligent packaging of meat is quite open to improvement with new researches.

\section{References}

Aghaei E, Emadzadeh B, Ghorani B, Kadkhodaee R. 2018. Cellulose acetate nanofibres containing alizarin as a halochromic sensor for the qualitative assesment of rainbow trout fish spoilage. Food and Bioprocess Technology, 11: 1087-1095.

Aghaei E, Ghorani B, Emadzadeh B, Kadkhodaee R, Tucker N. 2020. Protein-based halochromic electrospun nanosensor for monitoring trout fish freshness. Food Control, 111: 107065.

Alizadeh-Sani M, Tavassoli M, Mohammadian E, Ehsani A, Khaniki GJ, Priyadarshi R, Rhim J-W. 2020. pH-responsive color indicator films based on methylcellulose/chitosan nanofiber and barberry anthocyanins for real-time monitoring of meat freshness. International Journal of Biological Macromolecules, 166: 741-750.

Chen H, Zhang M, Bhandari B, Yang C. 2020. Novel pHsensitive films containing curcumin and anthocyanins to monitor fish freshness. Food Hydrocolloids, 100: 105438.

Çelik İ, Tümer G. 2016. Gıda ambalajlamada son gelişmeler. Akademik Gıda, 14(2): 180-188.

Demirel B. 2019. Development of freshness indicator for monitoring of spoilage on chicken meat. MSc Thesis, Institute of Science and Technology, Hacettepe University, Ankara, Turkey.

Dong H, Ling Z, Zhang X, Zhang X, Ramaswamy S, Xu F. 2020. Smart colorimetric sensing films with high mechanical strength and hydrophobic properties for visual monitoring of shrimp and pork freshness. Sensors and Actuators: B. Chemical, 309: 127752.

Dudnyk I, Janecek ER, Joset JV, Stellacci F. 2018. Edible sensors for meat and seafood freshness. Sensors and Actuators: B. Chemical, 259: 1108-1112.

Er B. 2016. The effects of curcumin supplementation on some apoptotic markers in laying hens, a preclinical model for human ovarian cancer. MSc Thesis, Institute of Science and Technology, Firat University, Elazığ, Turkey.

Etxabide A, Kilmartin PA, Mate JI. 2021. Color stability and pHindicator ability of curcumin, anthocyanin and betanin containing colorants under different storage conditions for intelligent packaging development. Food Control, 121: 107645.

Ezati P, Bang Y, Rhim J-W. 2021. Preparation of a shikoninbased $\mathrm{pH}$-sensitive color indicator for monitoring the freshness of fish and pork. Food Chemistry, 337: 127995.

Ezati P, Rhim J-W. 2020. pH-responsive pectin-based multifunctional films incorporated with curcumin and sulfur nanoparticles. Carbohydrate Polymers, 230: 115638.

Ezati P, Rhim J-W, Moradi M, Tajik H, Molaei R. 2020. CMC and CNF-based alizarin incorporated reversible $\mathrm{pH}-$ responsive color indicator films. Carbohydrate Polymers, 246: 116614.

Ezati P, Tajik H, Moradi M. 2019. Fabrication and characterization of alizarin colorimetric indicator based on cellulose-chitosan to monitor the freshness of minced beef. Sensors and Actuators: B. Chemical, 285: 519-528.

Fei P, Zeng F, Zheng S, Chen Q, Hu Y, Cai J. 2021. Acylation of blueberry anthocyanins with maleic acid: Improvement of the stability and its application potential in intelligent color indicator packing materials. Dyes and Pigments, 184: 108852.

Filho JGO, Braga ARC, Oliveira BR, Gomes FP, Moreira VL, Pereira VAC, Egea MB. 2021. The potential of anthocyanins in smart, active, and bioactive eco-friendly polymer-based films: A review. Food Research International, 142: 110202.

Fu L, Wang A, Zhang H, Zhou Q, Chen F, Su W, Yu A, Ji Z, Liu Q. 2019. Analysis of chicken breast meat freshness with an electrochemical approach. Journal of Electroanalytical Chemistry, 855: 113622.

Huang XW, Zou XB, Shi JY. 2014. Determination of pork spoilage by colorimetric gas sensor array based on natural pigments. Food Chemistry, 145: 549-554.

Ian M, Fiona J, Christopher BC. 2020. An edible genipin-based sensor for biogenic amine detection. journal of chemical technology and biotechnology, doi: https://doi.org/jctb.6556

Jiang G, Hou X, Zeng X, Zhang C, Wu H, Shen G, Li S, Luo Q, Li M, Liu X, Chen A, Wang Z, Zhang Z. 2020. Preparation and characterization of indicator films from carboxymethylcellulose/starch and purple sweet potato (Ipomoea batatas (L.) lam) anthocyanins for monitoring fish freshness. International Journal of Biological Macromolecules, 143: 359-372.

Kanatt SR. 2020. Development of active/intelligent food packaging film containing Amaranthus leaf extract for shelflife extension of chicken/fish during chilled storage. Food Packaging and Shelf Life, 24: 100506.

Katmer K. 2015. Improving the water solubility of curcumin. MSc Thesis, Graduate School of Science Engineering and Technology, Istanbul Technical University, Istanbul, Turkey. Kuntzler SG, Costa JAV, Brizio APDR, de Morais MG. 2020. 
Development of a colorimetric $\mathrm{pH}$ indicator using nanofibers containing Spirulina sp. LEB 18. Food Chemistry, 328: 126768.

Kürek M, Hlupic L, Scetar M, Bosiljkov T, Galic K. 2019. Comparison of two $\mathrm{pH}$-responsive color-changing bio-based films containing wasted fruit pomace as a source of colorants. Journal of Food Science, 84(9): 2490-8. doi: 10.1111/17503841.14716.

Lafarga T, Fernandez-Sevilla JM, Gonzalez-Lopez C, AcienFernandez FG. 2020. Spirulina for the food and functional food industries. Food Research International, 137: 109356.

Latos-Brozio M, Masek A. 2020. The application of natural food colorants as indicator substances in $\mathrm{T}$ intelligent biodegradable packaging materials. Food and Chemical Toxicology, 135: 110975.

Li Y, Wu K, Wang B, Li X. 2021. Colorimetric indicator based on purple tomatoe anthocyanins and chitosan for application in intelligent packaging. International Journal of Biological Macromolecules, 174: 370-376.

Liu J, Wang H, Wang P, Guo M, Jiang S, Li X, Jiang S. 2018. Films based on $\kappa$-carrageenan incorporated with curcumin for freshness monitoring. Food Hydrocolloids, 83: 134-142.

Luo X, Lim L-T. 2020. Curcumin-loaded electrospun nonwoven as a colorimetric indicator for volatile amines. LWT - Food Science and Technology, 128: 109493.

Mohammadalinejhad S, Almasi H, Moradi M. 2020. Immobilization of Echium amoenum anthocyanins into bacterial cellulose film: A novel colorimetric $\mathrm{pH}$ indicator for freshness/spoilage monitoring of shrimp. Food Control, 113: 107169. doi: https://doi.org/10.1016/j.foodcont.2020.1071 69.

Moreira JB, Terra ALM, Costa JAV, De Morais MG. 2018. Development of $\mathrm{pH}$ indicator from PLA/PEO ultrafine fibers containing pigment of microalgae origin. International Journal of Biological Macromolecules, 118 (Part B): 18551862.

Özkaya PT, Kayaardı S. 2018. Et ve et ürünlerinin kalitesini geliştirmede kullanılan yeni teknikler. Akademik Gıda 16(3): 323-331, doi: 10.24323/akademik-gida.475368.

Roy S, Rhim J-W. 2020. Anthocyanin food colorant and its application in $\mathrm{pH}$-responsive color change indicator films. Critical Reviews in Food Science and Nutrition, doi: 10.1080/10408398.2020.1776211.

Taherkhani E, Moradi M, Tajik H, Molaei R, Ezati P. 2020. Preparation of on-package halochromic freshness/spoilage nanocellulose label for the visual shelf-life estimation of meat. International Journal of Biological Macromolecules, 164: 2632-2640.

Takma DK, Nadeem HŞ. 2019. Gıdalarda akıllı ambalajlama teknolojisi ve güncel uygulamalar. GIDA, 44(1): 131-142. doi: 10.15237/gida.GD18106.

Talukder S, Mendiratta SK, Kumar RR, Agrawal RK, Soni A, Luke A, Chand S. 2020. Jamun fruit (Syzgium cumini) skin extract-based indicator for monitoring chicken patties quality during storage. Journal of Food Science and Technology, 57: 537-548.
Terra ALM, Moreira JB, Costa JAV, De Morais MG. 2021. Development of time-pH indicator nanofibers from natural pigments: An emerging processing technology to monitor the quality of foods. LWT - Food Science and Technology, 142: 111020.

Wu C, Sun J, Chen M, Ge Y, Ma J, Hu Y, Pang J, Yan Z. 2019. Effect of oxidized chitin nanocrystals and curcumin into chitosan films for seafood freshness monitoring. Food Hydrocolloids, 95: 308-317.

Yıldız E, Sumnu G, Kahyaoğlu LN. 2021. Monitoring freshness of chicken breast by using natural halochromic curcumin loaded chitosan/PEO nanofibers as an intelligent package. International Journal of Biological Macromolecules, 170: 437-446.

Yong H, Liu J. 2020. Recent advances in the preparation, physical and functional properties, and applications of anthocyaninsbased active and intelligent packaging films. Food Packaging and Shelf Life, 26: 100550.

Zeng P, Chen X, Qin Y, Zhang Y, Wang X, Wang J, Ning Z, Ruan Q, Zhang Y. 2019. Preparation and characterization of a novel colorimetric indicator film based on gelatin/polyvinyl alcohol incorporating mulberry anthocyanin extracts for monitoring fish freshness. Food Research International, 126: 108604.

Zhai X, Li Z, Shi Y, Huang X, Sun Z, Zhang D, Zou X, Sun Y, Zhang J, Holmes M, Gong Y, Povey M, Wang S. 2019. A colorimetric hydrogen sulfide sensor based on gellan gumsilver nanoparticles bionanocomposite for monitoring of meat spoilage in intelligent packaging. Food Chemistry, 290: 135143.

Zhai X, Wang X, Zhang J, Yang Z, Sun Y, Li Z, Huang X, Holmes M, Gong Y, Povey M, Shi J, Zou X. 2020. Extruded low-density polyethylene-curcumin film: A hydrophobic ammonia sensor for intelligent food packaging. Food Packaging and Shelf Life, 26: 100595.

Zhang J, Zou X, Zhai X, Huang X, Jiang C, Holmes M. 2019. Preparation of an intelligent $\mathrm{pH}$ film based on biodegradable polymers and roselle anthocyanins for monitoring pork freshness. Food Chemistry, 272: 306-312.

Zhang K, Huang T-S, Yan H, Hu X, Ren T. 2020. Novel pHsensitive films based on starch/polyvinyl alcohol and food anthocyanins as a visual indicator of shrimp deterioration. International Journal of Biological Macromolecules, 145: 768-776. doi: 10.1016/j.ijbiomac.2019.12.159. Epub 2019 Dec 20.

Zhang J, Huang X, Zou X, Shi J, Zhai X, Liu L, Li Z, Holmes M, Gong Y, Povey M, Xiao J. 2021. A visual indicator based on curcumin with high stability for monitoring the freshness of freshwater shrimp, Macrobrachium rosenbergii. Journal of Food Engineering, 292: 110290.

Zhou X, Yu X, Xie F, Fan Y, Xu X, Qi J, Xiong G, Gao X, Zhang F. 2021. pH-responsive double-layer indicator films based on konjac glucomannan/ camellia oil and carrageenan/ anthocyanin/curcumin for monitoring meat freshness. Food Hydrocolloids 118: 106695. 